\title{
PERAN PEER GROUP DALAM MELAKUKAN DETEKSI DINI MELALUI PEMERIKSAAN PAYUDARA SENDIRI (SADARI) SEBAGAI UPAYA PENCEGAHAN KANKER PAYUDARA PADA REMAJA
}

\author{
Riski Akbarani ${ }^{1}$, Eva Inayatul faiza ${ }^{2}$ \\ ${ }^{12}$ Sekolah Tinggi Ilmu Kesehatan Kendedes Malang
}

\begin{abstract}
Ensuring healthy lives and promoting well-being for all at all ages by 2030 is the third Target of the SDGs. The targets include efforts to reduce deaths from non-communicable diseases including breast cancer. The incidence of breast cancer increases with age, but we can prevent this cancer and if detected early, we will get better treatment. Early detection through BSE which is carried out starting at the age of adolescence with increased vigilance and is believed to be able to reduce mortality from breast cancer. The general purpose of this study was to determine the role of peer groups in conducting early detection through breast self-examination (BSE) as an effort to prevent breast cancer. This research is a research with pre test and post test with control group design. The sampling technique is purposive sampling. Data collection using questionnaires through google forms, checklists and modules. Analysis using Paired Sample T-test with the result $0.000<(\alpha)$ 0.05. This shows that there is a significant difference between the average scores before and after being given breast cancer health education. The conclusion is that there is a significant increase between peer education and BSE practice skills in adolescent girls. Peer youth educators are considered more influential on BSE abilities than teachers. Active learning methods provided by peer educators can increase the ability of self-awareness of adolescents.
\end{abstract}

Keywords: Peer Group, SADARI, Breast Cancer

\section{A. PENDAHULUAN}

Indonesia sebagai negara berkembang mempunyai Angka kejadian penyakit kanker sebesar 136.2/100.000 penduduk menduduki urutan 8 di Asia Tenggara dan urutan ke 23 di Asia. Angka kejadian tertinggi untuk laki laki adalah kanker paru yaitu sebesar 19,4 per 100.000 penduduk dengan rata-rata kematian 10,9 per 100.000 penduduk, yang diikuti dengan kanker hati sebesar 12,4 per 100.000 penduduk dengan rata-rata kematian 7,6 per 100.000 penduduk. Sedangkan angka kejadian untuk perempuan yang tertinggi adalah kanker payudara yaitu sebesar 42,1 per 100.000 penduduk dengan rata-rata kematian 17 per 100.000 penduduk yang diikuti kanker leher rahim sebesar 23,4 per 100.000 penduduk dengan rata-rata kematian 13,9 per 100.000 penduduk (Depkes RI, 2019).

Kanker payudara yang juga disebut ca mamae merupakan pertumbuhan sel payudara yang tidak terkontrol karena terjadi perubahan abnormal dari gen yang berperan dalam pembelahan sel (Pusdatin, 2015). Kanker payudara sampai saat ini masih menjadi masalah karena merupakan jenis kanker yang angka kejadiannya paling tinggi di Indonesia. Kejadian kanker payudara meningkat sesuai dengan bertambahnya usia. Akan tetapi, usia muda juga bukan jaminan aman dari kanker payudara (KPKN, 2015). 
Tujuan Sustainable Development Goals (SDGs) pada target ketiga adalah menjamin kehidupan yang sehat dan mendorong kesejahteraan bagi semua orang di segala usia pada tahun 2030 (WHO,2016). Dalam target tersebut terdapat upaya untuk mengurangi kejadian kematian akibat penyakit tidak menular termasuk kanker payudara. Oleh karena itu paradigma sehat yang mengedepankan konsep promotif dan preventif dalam pelayanan kesehatan merupakan prioritas target SDGs di Indonesia (Bappenas, 2020).

Konsep promotif dan preventif yang dilakukan oleh pemeritah terhadap kasus penyakit tidak menular terutama kanker payudara adalah dengan melakukan deteksi dini kanker payudara melalui Pemeriksaan Payudara Sendiri (SADARI). Penyakit kanker bisa kita cegah dan bila diketahui sejak dini memiliki kemungkinan untuk mendapatkan penanganan menjadi lebih baik. Oleh karena itu untuk meningkatkan kesadaran dalam mengenali gejala dan risiko kanker payudara dapat dilakukan pencegahan dan deteksi dini yang tepat melalui Pemeriksaan Payudara Sendiri (SADARI) (Kemenkes RI, 2019).

Insiden kanker payudara meningkat sesuai dengan bertambahnya usia. Akan tetapi, usia muda juga bukan jaminan aman dari kanker payudara. Remaja sebagai kelompok umur terbesar dalam struktur penduduk Indonesia dapat menjadi fokus perhatian dan titik intervensi bagi pembangunan sumber daya manusia terutama untuk pencegahan penyakit kanker. Deteksi dini melalui SADARI yang dilakukan mulai usia remaja dengan peningkatan kewaspadaan dan dipercaya dapat menurunkan jumlah kematian karena kanker payudara. Motivasi remaja putri dalam melakukan SADARI berbeda-beda, hal tersebut dapat dipengaruhi oleh karena meniru orang lain, pergaulan, ajakan teman, dan kesenangan. Melalui kelompok sebaya (peer group) diharapkan terjadi perubahan perilaku kesehatan pada remaja putri, karena edukasi kelompok sebaya terbukti efektif mempengaruhi perubahan perilaku (Aisha, dkk. 2010). Tujuan pemilihan peer group ini dikarenakan peer group memiliki peran reinforcement social, modeling, objek perbandingan sosial dan persuasi sehingga dapat memberikan pengaruh kuat pada kelompok sebaya dimana remaja lebih banyak berada diluar rumah bersama dengan teman-teman sebaya, sehingga pengaruh teman sebaya lebih besar dari pada pengaruh keluarga ataupun petugas kesehatan.

Oleh karena itu tujuan umum dari penelitian ini adalah untuk mengetahui peran peer group dalam melakukan deteksi dini melalui pemeriksaan payudara sendiri (SADARI) sebagai upaya pencegahan kanker payudara.

\section{B. TINJAUAN PUSTAKA}

\section{Peer Group Remaja}

Peer group merupakan suatu bentuk hubungan sosial yang dibangun dan bersumber dari teman sebaya, mereka akan menawarkan dan memberikan bantuan kepada teman lainnya ketika teman sebayanya tersebut mengalami kesulitan. Hubungan di dalam teman sebaya dapat berupa pemberian informasi, bantuan, atau materi. Dukungan teman sebaya membuat anak merasa diperhatikan, dihargai, dicintai, dibantu, didorong, dan diterima ketika dalam kesulitan (Aprilia dan Bondika, 2011). Sedangkan untuk Batasan remaja menurut WHO adalah suatu masa dimana secara fisik individu berkembang dari saat pertama kali menunjukan tandatanda seksual sekunder sampai 
mencapai kematangan seksual, secara psikologis individu mengalami perkembangan dan pola identifikasi dari kanak-kanak menjadi dewasa dengan batasan usia 10-20 tahun (Sarwono, 2011).

Faktor pembentuk perilaku remaja berasal dari internal dan eksternal. Faktor Internal merupakan potensi yang ada pada diri seseorang sejak lahir. Harga diri dan kecerdasan merupakan faktor internal yang paling berpengaruh terhadap perilaku sosial. Faktor eksternal yaitu berasal dari pengalaman atau lingkungan yang berpengaruh terhadap perilaku sosial remaja (Sarwono,2012). Pengaruh sosial khususnya dari tenaga kesehatan yang kuat dapat mengubah sikap remaja putri akan suatu kepercayaan atau kejadian dan merujuk pada suatu perilaku deteksi dini kanker payudara. Hubungan yang di bentuk oleh remaja putri bersama teman sebayanya berdampak akan sikap dan pandang remaja putri untuk melakukan deteksi dini kanker payudara (Myers, 2012).

\section{Kanker Payudara}

Kanker payudara merupakan kanker yang berasal dari kelenjar, saluran kelenjar dan jaringan yang menunjang payudara. Sejumlah sel dalam payudara tumbuh dan berkembang dengan tidak terkendali inilah yang disebut dengan kanker payudara (Ariani dan Sofi, 2015).

Faktor risiko kanker payudara dapat dibagi menjadi faktor reproduksi, faktor endokrin, faktor diet dan faktor genetik. Berikut adalah faktor reproduksi (Rasjidi dan Imam. 2010) :

\section{Faktor Reproduksi}

a) Menarche dini atau menstruasi pertama pada usia muda relatif muda (kurang dari 12 tahun) berhubungan dengan peningkatan risiko kanker payudara. Didapatkan bahwa pada usia menarche yang lebih muda terdapat peningkatan risiko kanker payudara.

b) Risiko kanker payudara menunjukan peningkatan seiring dengan peningkatan usia saat kehamilan pertama atau melahirkan anak pertama pada usia relatif tua (>35 tahun).

c) Paritas yang rendah Studi meta-analisis menunjukan bahwa pada wanita nullipara atau belumpernah melahirkan mempunyai risiko $30 \%$ untuk berkembang menjadi kanker dibandingkan dengan wanita yang multipara.

d) Masa laktasi Menurut Byers dkk bahwa adanya efek bersifat protektif dari menyusui terhadap kanker payudara. Hal ini dikarenakan adanya penurunan level esterogen dan sekresi bahan-bahan karsinogenik selama menyusui.

2. Faktor endokrin

a) Beberapa studi menyebutkan bahwa kontrasepsi oral berperan dalam peningkatan risiko kanker payudara pada wanita pra menopause.

b) Studi meta analisis menunjukan bahwa terapi sulih hormone (TSH) dapat meningkatkan risiko kanker payudara. 
3. Diet

a) Konsumsi makanan berlemak dengan frekuensi yang tinggi lemak akan dapat meningkatkan produksi esterogen karena meningkatnya pembentukan jaringan adipose.

b) Konsumsi alkohol dapat menyebabkan hiperinsulinemia yang akan merangsang faktor pertumbuhan pada jaringan payudara. Hal ini akan merangsang pertumbuhan yang tergantung esterogen pada lesi pra kanker yang selama masa menopause akan mengakami regresi ketika jumlah esterogen menurun.

c) Obesitas Berdasarkan American Cancer Society menyatakan bahwa wanita yang mengalami obesitas setelah memasuki masa menopause memiliki risiko lebih tingi menderita kanker payudara (Ades. dkk, 2014).

4. Genetik Mutasi yang paling banyak terjadi pada kanker payudara adalah gen BRCA 1 dan BRCA 2. Pada sel normal gen ini membantu mencegah terjadinya kanker dengan jalan menghasilkan proten yang dapat mencegah pertumbuhan abnormal.

Tanda dan Gejala Kanker Payudara Menurut Ariani (2015) bahwa ada gejala dan tanda dini kanker payudara yang dikeluhkan penderita yaitu berupa benjolan yang dapat dirasakan oleh penderita. Benjolan awal ini tidak menimbulkan rasa sakit tetapi membuat permukan sebelah pinggir payudara tidak teratur. Semakin membesar kanker pada payudara membuat benjolan yang menempel pada kulit sehinga menimbulkan borok. Gejala kanker payudara lainya dapat ditemukan berupa benjolan pada ketiak, perubahan ukuran dan bentuk payudara, keluar cairan darah atau berwarna kuning sampai kehijau-hijauan yang berupa nanah. Ditandai juga dengan putting susu atau areola (daerah coklat di sekeliling susu) payudara tampak kerahan dan putting susu tertarik ke dalam atau terasa gatal (Ariani dan Sofi, 2015).

\section{Deteksi Dini Kanker Payudara dengan SADARI}

\section{(Pemeriksaan Payudara Sendiri)}

Pemeriksaan payudara sendiri adalah suatu upaya pendeteksi dini terjadinya kanker payudara. Pencegahan untuk deteksi sini ada tidaknya kanker payudara lebih baik daripada mengobati pada saat keadaan kanker payudara pada stadium lanjut dan menjadi lebih berat penanganannnya (Mumpuni dan Andang, 2013). SADARI adalah metode pencegahan kedua yang digunakan untuk pemeriksaan deteksi dini kanker payudara selain mamografi dan pemeriksaan secara klinis. SADARI merupakan salah satu metode deteksi kanker payudara yang dikemukan oleh American Cancer Society (ACS) dan dianjurkan dilakukan sendiri ketika memasukki usia 20 tahun, serta tidak memerlukan biaya (Ariani dan Sofi, 2015). Program deteksi dini kanker payudara yang dianjurkan oleh American Cancer Society adalah sebagai berikut:

1) Umur 20-25 tahun: SADARI satu bulan sekali

2) Umur 25-35 tahun: SADARI satu bulan sekali dan pemeriksaan dokter 1 tahun sekali. 
3) Umur 35 tahun: basaline mammografi

4) Umur $>35-50$ tahun: SADARI satu bulan sekali, pemeriksaan dokter 6 bulan sekali dan mammografi sesuai anjuran dokter.

5) Usia > 50 tahun: SADARI satu bulan sekali, pemeriksaan dokter 6 bulan sekali dan mammografi satu tahun sekali.

Waktu pelaksanaan yang tepat untuk melakukan SADARI yaitu hari ke 7 sampai 10 terhitung sejak hari pertama menstruasi. Langkah SADARI, Wanita hendaknya sadar akan bagiamana keadaan normal payudaranya kemudian melakukan gerakan dibawah ini (Ades. dkk, 2014) :

1) Berbaring dan tempatkan tangan kanan dibelakang kepala. Pemeriksaan ini dilakukan dengan berbaring dan bukan berdiri. Sebab ketika berbaring, jaringan payudara menyebar rata disekitar dinding dada, dan menjadi setipis mungkin sehingga lebih mudah untuk merasakan seluruh jaringan payudara.

2) Gunakan buku jari dari ketiga jari tengah tangan kiri. Untuk merasakan benjolan pada payudara. Gerakan buku jari melingkar keluar dari arah dalam keluar untuk merasakan jaringan payudara.

3) Gunakan tiga tingkatan tekanan yang berbeda untuk merasakan seluruh jaringan payudara. Tekanan ringan digunakan untuk merasakan jaringan payudara yang terdekat dengan kulit. Tekanan sedang digunakan untuk memeriksa bagian tengah payudara. Dan tekanan berat digunakan untuk merasakan jaringan payudara yang paling dekat dengan dada dan tulang iga.

4) Sentuh payudara dapan gerakan naik-turun dimulai pada garis lurus imajiner pada bawah ketiak dan menuju melalui payudara ke tangah tulang dada.

5) Ulangi pemeriksaan pada payudara kiri menggunakan buku jari tangan kanan. Periksa ketiak ketika duduk atau berdiri dengan tangan sedikit terangkat sehingga dapat dengan mudah merasakan area ketiak

\section{METODE PENELITIAN}

Rancangan Pada penelitian ini, menggunakan jenis penelitian quasy experimental dengan pre testand post test with control group design untuk mengetahui seberapa optimal peer group dalam melakukan deteksi dini melalui pemeriksaan payudara sendiri (SADARI) sebagai upaya pencegahan kanker payudara pada remaja.

Desain penelitian yang digunakan dalam penelitian ini adalah "One Groups Pretest-Posttest Design", yaitu desain penelitian yang terdapat pretest sebelum diberi perlakuan dan posttest setelah diberi perlakuan. Dengan demikian dapat diketahui lebih akurat, karena dapat membandingkan dengan diadakan sebelum diberi perlakuan.

Hal pertama dalam pelaksanaan ini dilakukan dengan memberikan tes kepada sampel yang disebut pre test $\left(\mathrm{O}_{1}\right)$ untuk mengetahui tingkat pengetahuan remaja. Setelah didapat hasil, maka dilakukan treatment $(\mathrm{X})$ yaitu pelatihan sadari dimana remaja dibagi menjadi 2 kelompok yaitu Kelompok eksperimen diberikan pelatihan SADARI oleh peergroup $\left(\mathrm{X}_{1}\right)$ dan kelompok pembanding yang diberikan pelatihan 
secara penyuluhan $\left(\mathrm{X}_{2}\right)$. Setelah dilakukan perlakuan kepada seluruh remaja, maka diberikan lagi tes), dalam post test akan didapatkan data hasil dari eksperimen Bandingkan $\mathrm{O}_{1}$ dan $\mathrm{O}_{2}$ untuk menentukan seberapa besar perbedaan yang timbul, jika sekiranya ada sebagai akibat diberikannya variabel eksperimen. Kemudian data tersebut dianalisis dengan menggunakan t-test

Kelompok Eksperimen Pretest Perlakuan Postest

$$
\mathrm{O}_{1} \rightarrow \quad \mathrm{X}_{1} \rightarrow \quad \mathrm{O}_{2}
$$

Kelompok Pembanding Pretest Perlakuan Postest

$$
\mathrm{O}_{1} \rightarrow \quad \mathrm{X}_{2} \rightarrow \quad \mathrm{O}_{2}
$$

Keterangan :

$\mathrm{O}_{1}$ : Kompetensi remaja putri sebelum diberikan pelatihan SADARI

$\mathrm{X}_{1}$ : Pelatihan SADARI dengan metode peer group

$\mathrm{X}_{2}$ : Pelatihan SADARI dengan metode penyuluhan

$\mathrm{O}_{2}$ : Kompetensi remaja putri setelah diberikan pelatihan SADARI

\section{HASILPENELITIAN}

Dari kegiatan penelitian yang telah dilakukan pada bulan Agustus sampai dengan September 2021 didapatkan data karakteristik remaja di lokasi penelitian sebagai berikut:

Tabel 1 karakteristik Responden Berdasarkan Usia

\begin{tabular}{|l|c|c|}
\hline Karakteristik & Frekuensi (N) & Persentase (\%) \\
\hline $\mathbf{1 8 - 2 0}$ Tahun & 20 & $33,3 \%$ \\
\hline $\mathbf{2 1 - 2 3}$ Tahun & 35 & $58,3 \%$ \\
\hline $\mathbf{2 3 - 2 5}$ Tahun & 5 & $8,4 \%$ \\
\hline Jumlah & $\mathbf{6 0}$ & $\mathbf{1 0 0} \%$ \\
\hline
\end{tabular}

Data karakteristik responden berdasarkan usia yang ditunjukkan dalam tabel 1 menunjukkan sebagian besar berusia 21-23 tahun sebanyak 58,3\%. 
Tabel 2. Tingkat Pengetahuan Remaja Putri Pada Kelompok Pembanding

\begin{tabular}{|l|c|c|c|c|c|c|c|}
\hline \multirow{2}{*}{$\begin{array}{l}\text { Kelompok } \\
\text { Pembanding }\end{array}$} & \multicolumn{6}{|c|}{ Tingkat Pengetahuan } \\
\cline { 2 - 8 } & \multicolumn{2}{|c|}{ Baik } & \multicolumn{2}{|c|}{ Cukup } & \multicolumn{2}{c|}{ Kurang } & Jumlah \\
\cline { 2 - 8 } & f & $\%$ & f & $\%$ & f & $\%$ & \\
\hline Pre Test & 5 & 16,66 & 5 & 16,66 & 20 & 66,68 & 30 \\
\hline Post Test & 10 & 33,32 & 20 & 66,68 & 0 & 0 & 30 \\
\hline
\end{tabular}

Berdasakan Tabel 2 diatas menunjukkan pengetahuan remaja putri tentang kanker payudara pada kelompok pembanding sebelum diberikan perlakuan dalam bentuk penyuluhan memiliki tingkat pengetahuan kategori Baik 16,66\% Cukup 16,66\% dan Kurang $66,68 \%$. Sesudah diberikan perlakuan dalam bentuk penyuluhan memiliki tingkat pengetahuan kategori Baik 33,32\% Cukup 66,68\% dan Kurang $0 \%$.

Tabel 3. Tingkat Pengetahuan Remaja Putri Pada Kelompok Eksperimen

\begin{tabular}{|l|c|c|c|c|c|c|c|}
\hline \multirow{2}{*}{$\begin{array}{l}\text { Kelompok } \\
\text { Eksperimen }\end{array}$} & \multicolumn{6}{|c|}{ Tingkat Pengetahuan } & \multirow{2}{*}{ Jumlah } \\
\cline { 2 - 8 } & \multicolumn{2}{|c|}{ Baik } & \multicolumn{2}{|c|}{ Cukup } & \multicolumn{2}{c|}{ Kurang } & \multirow{2}{*}{} \\
\cline { 2 - 8 } & $\mathbf{f}$ & $\%$ & $\mathbf{f}$ & $\%$ & $\mathbf{f}$ & $\%$ & \\
\hline Pre Test & 6 & 16,67 & 8 & 26,66 & 14 & 56,67 & 30 \\
\hline Post Test & 25 & 83,33 & 5 & 16,66 & 0 & 0 & 30 \\
\hline
\end{tabular}

Berdasarkan Tabel 3 diatas menunjukkan pengetahuan remaja putri tentang kanker payudara pada kelompok Eksperimen yang menggunakan peer group sebelum diberikan pendidikan kesehatan memiliki tingkat pengetahuan kategori Baik 16,67\% Cukup 26,66\% dan Kurang 56,67\%, Sesudah diberikan perlakuan dalam bentuk pendidikan kesehatan memiliki tingkat pengetahuan kategori Baik 83,33\% Cukup 16,66 dan Kurang 0\%.

Tabel 4. Tingkat Perilaku SADARI Remaja Putri Pada Kelompok Pembanding

\begin{tabular}{|l|c|c|c|c|c|c|c|}
\hline \multirow{2}{*}{$\begin{array}{l}\text { Kelompok } \\
\text { Pembanding }\end{array}$} & \multicolumn{6}{|c|}{ Tingkat Perilaku } & \multirow{2}{*}{ Jumlah } \\
\cline { 2 - 8 } & \multicolumn{2}{|c|}{ Baik } & \multicolumn{2}{|c|}{ Cukup } & \multicolumn{2}{c|}{ Kurang } & \multirow{2}{*}{} \\
\cline { 2 - 8 } & f & \% & f & \% & f & \% & \\
\hline Pre Test & 2 & 6,67 & 4 & 13,34 & 24 & 79,99 & 30 \\
\hline Post Test & 7 & 23,33 & 19 & 63,33 & 4 & 13,34 & 30 \\
\hline
\end{tabular}


Berdasakan Tabel 4 diatas menunjukkan Perilaku remaja putri melakukan SADARI pada kelompok pembanding sebelum diberikan perlakuan dalam bentuk penyuluhan memiliki tingkat Perilaku kategori Baik 6,67\% Cukup 13,34\% dan Kurang 79,99\%. Sesudah diberikan perlakuan dalam bentuk penyuluhan memiliki tingkat Perilaku kategori Baik 23,33\% Cukup 63,33\% dan Kurang 13,34\%.

Tabel 5. Tingkat Perilaku Remaja Putri Pada Kelompok Eksperimen

\begin{tabular}{|l|c|c|c|c|c|c|c|}
\hline \multirow{2}{*}{$\begin{array}{l}\text { Kelompok } \\
\text { Eksperimen }\end{array}$} & \multicolumn{6}{|c|}{ Tingkat Perilaku } & \multirow{2}{*}{ Jumlah } \\
\cline { 2 - 7 } & \multicolumn{2}{|c|}{ Baik } & \multicolumn{2}{|c|}{ Cukup } & \multicolumn{2}{|c|}{ Kurang } & \multirow{2}{*}{ f } \\
\cline { 2 - 7 } & 4 & f & \% & f & \% & \\
\hline Pre Test & 4 & 13,34 & 3 & 10 & 23 & 76,66 & 30 \\
\hline Post Test & 24 & 80 & 6 & 20 & 0 & 0 & 30 \\
\hline
\end{tabular}

Berdasarkan Tabel 5 diatas menunjukkan Perilaku remaja putri melakukan SADARI pada kelompok Eksperimen yang menggunakan peer group sebelum diberikan pendidikan kesehatan memiliki tingkat Perilaku kategori Baik 13,34\% Cukup 10\% dan Kurang 76,66\%, SEdangkan Sesudah diberikan perlakuan dalam bentuk pendidikan kesehatan memiliki tingkat Perilaku kategori Baik 80\% Cukup 20\% dan Kurang 0\%.

Tabel 6. Tingkat Keterampilan Remaja Putri Pada Kelompok Pembanding

\begin{tabular}{|l|c|c|c|c|c|c|c|}
\hline \multirow{2}{*}{$\begin{array}{l}\text { Kelompok } \\
\text { Pembanding }\end{array}$} & \multicolumn{6}{|c|}{ Tingkat Keterampilan } & \multirow{2}{*}{ Jumlah } \\
\cline { 2 - 7 } & \multicolumn{2}{|c|}{ Baik } & \multicolumn{2}{|c|}{ Cukup } & \multicolumn{2}{|c|}{ Kurang } & \\
\cline { 2 - 7 } & f & $\%$ & f & $\%$ & f & $\%$ & \\
\hline Pre Test & 3 & 10 & 20 & 66,67 & 7 & 23,33 & 30 \\
\hline Post Test & 9 & 30 & 19 & 63,33 & 2 & 6,67 & 30 \\
\hline
\end{tabular}

Berdasakan Tabel 6 diatas menunjukkan Tingkat Keterampilan remaja putri dalam deteksi dini dengan SADARI pada kelompok pembanding sebelum diberikan perlakuan dalam bentuk penyuluhan memiliki tingkat Keterampilan kategori Baik $10 \%$ Cukup 66,67\% dan Kurang 23,33\%. Sesudah diberikan perlakuan dalam bentuk penyuluhan memiliki tingkat Keterampilan kategori Baik 30\% Cukup 63,33\% dan Kurang6,67\%. 
Tabel 7. Tingkat Keterampilan Remaja Putri Pada Kelompok Eksperimen

\begin{tabular}{|l|c|c|c|c|c|c|c|}
\hline \multirow{2}{*}{$\begin{array}{l}\text { Kelompok } \\
\text { Pembanding }\end{array}$} & \multicolumn{5}{|c|}{ Tingkat Keterampilan } & \multirow{2}{*}{ Jumlah } \\
\cline { 2 - 7 } & \multicolumn{2}{|c|}{ Baik } & \multicolumn{2}{|c|}{ Cukup } & \multicolumn{2}{c|}{ Kurang } & \multirow{2}{*}{} \\
\cline { 2 - 7 } & f & \% & f & \% & f & \% & \\
\hline Pre Test & 2 & 6,67 & 24 & 79,99 & 4 & 13,34 & 30 \\
\hline Post Test & 22 & 73,33 & 8 & 26,67 & 0 & 0 & 30 \\
\hline
\end{tabular}

Berdasarkan Tabel 7 Tingkat Keterampilan remaja putri dalam deteksi dini dengan SADARI pada kelompok Eksperimen yang menggunakan peer group sebelum diberikan pendidikan kesehatan memiliki tingkat Keterampil kategori Baik 6,67\% Cukup 79,99\% dan Kurang 13,34\%. Sesudah diberikan perlakuan dalam bentuk pendidikan kesehatan memiliki tingkat Keterampilan kategori Baik 73,33\% Cukup 26,67\% dan Kurang 0\%.

Tabel 8 Paired Sample Statistics peran peer group dalam melakukan deteksi dini melalui pemeriksaan payudara sendiri (SADARI)

\begin{tabular}{|l|l|c|c|c|c|}
\hline \multicolumn{2}{|c|}{ Mean } & N & $\begin{array}{c}\text { Std. } \\
\text { Deviation }\end{array}$ & $\begin{array}{c}\text { Std. Error } \\
\text { Mean }\end{array}$ \\
\hline \multirow{2}{*}{ Pair 1 } & Pre & 48.6777 & 30 & 12.55221 & 2.37345 \\
\cline { 2 - 6 } & Post & 84.0000 & 30 & 9.44211 & 1.63867 \\
\hline
\end{tabular}

Tabel 9. Paired Samples Correlations peran peer group dalam melakukan deteksi dini melalui pemeriksaan payudara sendiri (SADARI)

\begin{tabular}{|l|l|c|c|c|}
\hline \multicolumn{2}{|c|}{} & N & Correlation & Sig. \\
\hline Pair 1 & Pre \& Post & 30 & 780 & 000 \\
\hline
\end{tabular}


Tabel 10. Paired Samples Test peran peer group dalam melakukan deteksi dini melalui pemeriksaan payudara sendiri (SADARI)

\begin{tabular}{|c|c|c|c|c|c|c|c|c|c|}
\hline & \multicolumn{5}{|c|}{ Paired Differences } & \multirow{3}{*}{$\mathbf{t}$} & \multirow{3}{*}{ df } & \multirow{3}{*}{$\begin{array}{l}\text { Sig. (2- } \\
\text { tailed) }\end{array}$} \\
\hline & & \multirow[t]{2}{*}{ Mean } & \multirow[t]{2}{*}{$\begin{array}{l}\text { Std. } \\
\text { Dev }\end{array}$} & \multirow{2}{*}{$\begin{array}{l}\text { Std. } \\
\text { Error } \\
\text { Mean }\end{array}$} & \multicolumn{2}{|c|}{$\begin{array}{l}\text { 95\% Confidence } \\
\text { Interval of The } \\
\text { Difference }\end{array}$} & & & \\
\hline & & & & & Lower & Upper & & & \\
\hline $\begin{array}{l}\text { Pair } \\
1\end{array}$ & $\begin{array}{l}\text { Pre } \\
\& \\
\text { Post }\end{array}$ & $-34,444$ & 14.476 & 2.460 & $-38,465$ & -28.401 & $\begin{array}{l}- \\
13 . \\
654\end{array}$ & 29 & .000 \\
\hline
\end{tabular}

Hasil penelitian menunjukkan pengetahuan remaja putri tentang kanker payudara pada kelompok pembanding sebelum diberikan perlakuan dalam bentuk penyuluhan memiliki tingkat pengetahuan kategori Baik 16,66\% Cukup 16,66 \% dan Kurang $66,68 \%$. Sesudah diberikan perlakuan dalam bentuk penyuluhan memiliki tingkat pengetahuan kategori Baik 33,32\% Cukup 66,68\% dan Kurang $0 \%$. Sedangkan pada kelompok Eksperimen menunjukkan pengetahuan remaja putri tentang kanker payudara yang menggunakan peer group sebelum diberikan pendidikan kesehatan memiliki tingkat pengetahuan kategori Baik 16,67\% Cukup 26,66\% dan Kurang 56,67\%, Sesudah diberikan perlakuan dalam bentuk pendidikan kesehatan memiliki tingkat pengetahuan kategori Baik 83,33\% Cukup 16,66 dan Kurang 0\%.

Hasil uji Paired Sampel T-test metode peer group diperoleh signifikansi 0.000 kurang dari taraf signifikasi $(\alpha)$ 0,05 ini menunjukkan ada perbedaan signifikan antara rata-rata nilai sebelum dan sesudah di berikan pendidikan kesehatan tentang kanker payudara. Nilai $\mathrm{t}$ hitung negatif $(-13,654)$ artinya rata-rata sebelum diberikan pendidikan lebih rendah dari pada seseudah diberikan pendidikan kesehatan. Sehingga dapat disimpulkan terjadi peningkatan pengetahuan, perubahan perilaku dan peningkatan keterampilan dalam melakukan Deteksi Dini Melalui Pemeriksaan Payudara Sendiri (SADARI) pada remaja putri di Wilayah Kota Malang. Hasil penelitian ini sesuai dengan penelitian yang dilakukan oleh Yi dan Park (2012) mengatakan bahwa pendidikan kesehatan yang dilakukan secara profesional efektif meningkatkan pengetahuan dan praktik SADARI.

\section{E. PEMBAHASAN}

Pengetahuan adalah hasil tahu dan ini terjadi setelah seseorang melakukan pengindraan terhadap suatu obyek tertentu, tanpa pengetahuan seseorang tidak memiliki dasar untuk mengambil keputusan dan menentukan tindakan terhadap masalah yang dihadapi (Notoatmodjo, 2012). Pengetahun juga merupakan hasil dari informasi seseorang kepada orang lain yang belum tahu dan menjadi tahu untuk membentuk perilaku seseorang atau kelompok misalnya melalui pendidikan kesehatan. Metode peer group memiliki keefektifan yang lebih tinggi dibandingkan metode lain dalam promosi kesehatan. Kelompok teman sebaya juga berguna untuk berbagai pengalaman, saling mendukung, membangun kesadaran dan ide baru. Menurut penelitian Imron (2012) 
remaja lebih senang, nyaman dan terbuka apabila mendiskusikan permasalahan yang berhubungan dengan kesehatan reproduksinya dengan teman sebaya. Teman sebaya cenderung lebih berpengaruh dibandingkan dengan keluarga terhadap pengetahuan dan tindakan remaja. Dengan demikian informasi tentang deteksi dini kanker payudara melalui SADARI yang benar berasal dari remaja, ditransfer atau dikampanyekan oleh remaja dan untuk remaja ${ }^{14}$.

Tingkat pengetahuan seseorang sangat dipengaruhi oleh faktor internal dan eksternal. Menurut Notoatmodjo (2010) dalam bukunya berjudul Promosi kesehatan mengatakan bahwa pendidikan sangat erat dengan pengetahuan dimana diharapkan seseorang dengan pendidikan tinggi maka orang tersebut semakin luas pula pengetahuannya, namun perlu ditekankan bahwa seseorang yang berpendidikan rendah tidak berarti mutlak berpengetahuan rendah pula. Peningkatan pengetahuan tidak mutlak diperoleh pada pendidikan formal akan tetapi juga didapat pada pendidikan non formal. Faktor internal yang dapat mempengaruhi pengetahuan seseorang diantaranya adalah usia, pendidikan dan lama kerja ${ }^{15}$.

Hasil Penelitian menunjukkan Perilaku remaja putri melakukan SADARI pada kelompok pembanding sebelum diberikan perlakuan dalam bentuk penyuluhan memiliki tingkat Perilaku kategori Baik 6,67\% Cukup 13,34\% dan Kurang 79,99\%. Sesudah diberikan perlakuan dalam bentuk penyuluhan memiliki tingkat Perilaku kategori Baik 23,33\% Cukup 63,33\% dan Kurang 13,34\%. Sedangkan pada kelompok eksperimen menunjukkan Perilaku remaja putri melakukan SADARI yang menggunakan peer group sebelum diberikan pendidikan kesehatan memiliki tingkat Perilaku kategori Baik 13,34\% Cukup 10\% dan Kurang 76,66\%, SEdangkan Sesudah diberikan perlakuan dalam bentuk pendidikan kesehatan memiliki tingkat Perilaku kategori Baik 80\% Cukup 20\% dan Kurang 0\%.

Hasil penelitian ini menunjukkan ada perbedaan antara rata-rata nilai sebelum dan sesudah di berikan pendidikan kesehatan. Sehingga dapat disimpulkan terjadi peningkatan pada Perilaku SADARI pada remaja putri. Hasil penelitian ini sesuai dengan Penelitian Utami (2016) Mengatakan bahwa ada pengaruh pendidikan kesehatan teman sebaya terhadap perilaku SADARI. Menurut Notoatmodjo (2007) proses perubahan perilaku ada tiga domain yaitu pengetahuan, sikap, dan tindakan. Faktor yang mempengaruhi perilaku adalah motivasi, pengetahuan, sikap, kepercayaan, sarana prasarana, dan orang penting sebagai referensi ${ }^{16}$. Perilaku SADARI remaja putri dapat dipengaruhi oleh pengetahuan. Pengetahuan yang semakin baik dapat mempengaruhi sikap menjadi lebih baik. Sikap yang baik ini kemudian diimplementasikan dalam perilaku responden. Pengaruh pendidikan kesehatan terhadap perubahan perilaku SADARI remaja putri berdasarkan hasil penelitian diketahui terdapat perubahan perilaku responden setelah menerima pendidikan kesehatan. Menurut Notoatmodjo (2007) cara mengubah seseorang untuk berperilaku sesuai dengan nilai-nilai kesehatan adalah dengan pendidikan kesehatan. Pendidikan kesehatan adalah kegiatan untuk memberikan informasi dan meningkatkan pengetahuan, sikap serta tindakan baik individu, kelompok atau masyarakat dalam memelihara dan meningkatkan kesehatan mereka sendiri ${ }^{23}$.

Hasil penelitian ini sejalan dengan penelitian Astuti (2010) bahwa ada pengaruh pendidikan kesehatan terhadap perilaku SADARI. Pada penelitian ini dalam penyampaian pendidikan kesehatan menggunakan metode peer group atau teman sebaya karena peer group merupakan tempat di mana remaja sering berkumpul untuk 
mendiskusikan suatu masalah baik masalah yang menyenangkan atau menyedihkan yang dapat dipercaya. Disamping itu teman sebaya juga selalu melakukan perilaku tolong menolong, kerja sama walaupun ada yang melakukan persaingan karena berbeda minat atau keinginan. Pada penelitian ini peer group memberikan pengaruh yang positif terhadap responden, terbukti dengan adanya peningkatan pengetahuan, perilaku dan akhirnya diwujudkan melalui tindakan. Hasil pendidikan kesehatan peer group dalam memberikan informasi kesehatan selain meningkatkan pengetahuan juga meningkatkan sikap remaja putri dalam berperilaku (Mustikarani, 2018).

Hasil penelitian menunjukkan Tingkat Keterampilan remaja putri dalam deteksi dini dengan SADARI pada kelompok pembanding sebelum diberikan perlakuan dalam bentuk penyuluhan memiliki tingkat Keterampilan kategori Baik 10\% Cukup 66,67\% dan Kurang 23,33\%. Sesudah diberikan perlakuan dalam bentuk penyuluhan memiliki tingkat Keterampilan kategori Baik 30\% Cukup 63,33\% dan Kurang6,67\%. Sedangkan pada kelompok eksperimen Tingkat Keterampilan remaja putri dalam deteksi dini dengan SADARI yang menggunakan peer group sebelum diberikan pendidikan kesehatan memiliki tingkat Keterampil kategori Baik 6,67\% Cukup 79,99\% dan Kurang 13,34\%. Sesudah diberikan perlakuan dalam bentuk pendidikan kesehatan memiliki tingkat Keterampilan kategori Baik 73,33\% Cukup 26,67\% dan Kurang 0\%.

Hasil penelitian ini menunjukkan ada perbedaan signifikan antara rata-rata nilai sebelum dan sesudah di berikan pendidikan kesehatan. Sehingga dapat disimpulkan terjadi peningkatan Keterampilan Deteksi Dini dengan SADARI pada remaja putri. Hasil penelitian ini juga menunjukkan bahwa pendidikan kesehatan peer group tentang SADARI memberikan dampak positif pada peningkatan keterampilan remaja. Peningkatan keterampilan ini disebabkan karena adanya intervensi yang diberikan yakni pendidikan kesehatan melalui peer group sehingga pengetahuan remaja meningkat yang menyebabkan perubahan keterampilan. Hal ini sesuai dengan hasil penelitian Nisman (2008) yang menyatakan bahwa perlu diberdayakan pendidikan kesehatan peer group selama tiga kali pertemuan dapat meningkatkan pengetahuan kesehatan reproduksi remaja. Dari hasil penelitian ini, pendidikan kesehatan peer group dinilai efektif dalam menyampaikan informasi kesehatan pada kalangan remaja.

Menurut penelitian Hidayati (2011), dimana terdapat perbedaan rata-rata pengetahuan dan praktik SADARI sebelum dan setelah diberikan penyuluhan ${ }^{21}$. Penelitian Hendrik (2008) mengatakan terjadi peningkatan keterampilan interpensonal melalui konseling teman sebaya. Hal ini dapat dijelaskan bahwa dengan pengetahuan yang meningkat, maka keterampilan seseorang akan meningkat pula. Sedangkan menurut penelitian Damayanti, et al (2018) menyatakan bahwa ada peningkatan keterampilan SADARI responden secara signifikan setelah mendapat edukasi sebaya dengan menggunakan media video dan alat peraga. pengaruh pendidikan sebaya terhadap keterampilan praktik SADARI remaja putri. Pendidik remaja sebaya dianggap lebih memberikan pengaruh terhadap kemampuan SADARI dibandingkan oleh guru. Metode pembelajaran aktif yang diberikan oleh pendidik remaja sebaya dapat meningkatkan kemampuan SADARI remaja (Astuti, 2010).

Dengan memberikan penyuluhan dan tindakan langsung pemeriksaan payudara sendiri (SADARI) kepada responden diharapkan responden dapat meningkatkan pengetahuan dan keterampilan mempraktikkan tindakan SADARI dalam kehidupan sehari-hari dan dapat mengajarkan teman yang lainnya. 


\section{F. PENUTUP}

Berdasarkan penelitian dapat ditarik kesimpulan bahwa ada peningkatan keterampilan SADARI responden secara signifikan setelah mendapat edukasi sebaya dengan menggunakan media video dan alat peraga. pengaruh pendidikan sebaya terhadap keterampilan praktik SADARI remaja putri. Pendidik remaja sebaya dianggap lebih memberikan pengaruh terhadap kemampuan SADARI dibandingkan oleh guru. Metode pembelajaran aktif yang diberikan oleh pendidik remaja sebaya dapat meningkatkan kemampuan SADARI remaja

\section{G. DAFTAR PUSTAKA}

Ades, Terri, dkk. (2014). Cancer Fact and Figures 2014. Atlanta: American Cancer Of Society.

Aprilia Dian Utami dan Yuli Isnaeni (2016). Pengaruh Pendidikan Kesehatan Peer Group Terhadap Perilaku SADARI Pada Remaja Putri Di Dusun Celungan Sumberagung Moyudan Sleman. Naskah Publikasi. unisayogya.ac.id.

Aprilia, Bondika. (2011). Faktor yang Berhubungan dengan Pemilihan Jajanan pada Anak Sekolah Dasar. Artikel Penelitian. Semarang. Fakultas Kedokteran Universitas Diponegoro.

Ariani, Sofi. (2015). Stop Kanker. Yogyakarta: Istana Media

Astuti, D. (2010). Pengaruh Penyuluhan Kesehatan Tentang Kanker Payudara Terhadap Perilaku Pemeriksaan Payudara Sendiri Pada Wanita Usia Subur Di Dusun Besari Siraman Wonosari Gunungkidul. Tidak Dipublikasikan. Yogyakarta: STIKES ‘Aisyiyah Yogyakarta

Damayanti, A., Wulandari, Y., Hendrik., Elmansyah, T. (2008). Meningkatkan Keterampilan Interpersonal Melalui Konseling teman sebaya Sekolah Menengah Atas Negeri 1 Segedong. Jurnal Bimbingan Konseling Indonesia, 3 (1), p-ISSN: 2477-5916, e-ISSN: 24778370.

Hidayati, A. (2011). Pengaruh pendidikan kesehatan memalui metode ceramah dan demontrasi dalam meningkatkan pengetahuan tentang kanker payudara dan praktik SADARI pada Siswi kelas XII SMA Fatuhiyyah Mranggen Kabupaten Demak

Imron, A 2012. Pendidikan Kesehatan Reproduksi Remaja: Peer Educator \& Efektivitas Program PIK-KRR di sekolah. Yogyakarta: Ar-Ruzz Media

Kementrian Kesehatan RI (2019). Memperingati Hari Kanker Sedunia 2019. https://www.kemkes.go.id/article/view/19020100003/hari-kanker-sedunia 2019. html diakses tanggal 6 Oktober 2020

Kementrian PPN/Bappenas. (2020). Tujuan Pembangunan Berkelanjutan : Menjamin Kehidupan yang Sehat dan Meningkatkan Kesejahteraan Seluruh Penduduk Semua Usia http://sdgs.bappenas.go.id/tujuan-3/ diakses tanggal 20 Oktober 2020 
Komite Nasional Penanggulangan Kanker (KPKN). (2015). Panduan Nasional Penanganan Kanker Kanker Payudara. Jakarta : Kementrian Kesehatan RI.

Mumpuni, Y., dan Andang. (2013). 45 Penyakit Musuh Kaum Perempuan. Yogyakarta: Rapha Publishing

Mustikarani, I.K. (2018). Pengaruh peer Education tentang deteksi dini kanker payudara terhadap keterampilan praktik SADARI remaja putri di MAN 1 Surakarta. Stikes Kusuma Husada: Surakarta

Myers, D.G. (2012). Psikologi Sosial. Terjemahan. Jakarta: Salemba Humanika

Nisman, H. (2008). Pengaruh Penyampaian Pendidikan Kesehatan Reproduksi Oleh Kelompok Sebaya (Peer Group) Terhadap Pengetahuan Kesehatan Reproduksi Remaja Di SMP N 2 Kasihan Bantul. Yogykarta: UMY

Notoatmodjo, S. (2007). Promosi Kesehatan Teori Dan Aplikasi. Jakarta: Rineka Cipta

Notoatmojo. S., (2010). Promosi Kesehatan : Teori dan Aplikasi. Jakarta: PT Rineka Cipta.

Pusat data dan informasi. (2015). Situasi Penyakit Kanker di Indonesia. Jakarta : Kementrian Kesehatan RI.

Rahayu, Aminoto, Madkhan. (2011). Efektivitas Penyuluhan Peer Group Dengan Penyuluhan Oleh Petugas Kesehatan Terhadap Tingkat Pengetahuan Tentang Menarche. Jurnal Ilmiah Kesehatan Keperawatan.Volume 7. Gombong: STIKES Muhammadiyah.

Rasjidi, Imam. (2010). Epidemiologi Kanker Pada Wanita. CV Sagung Seto: Jakarta.

Sarwono, S. (2011). Psikologi Remaja. Jakarta: PT. Raja Grafindo.

Sarwono, S. (2012). Psikologi Remaja Edisi Revisi. Jakarta: PT Raja Grafindo Persada.

World Health Organization. (2016). What Is Breast Cancer. Available from:http://www.cancer.org/cancer/breast-cancer/detailedguide/breastcancerwhat-is-breast-cancer diakses tanggal 18 Oktober 2020

Yi, M., \& Park, E. Y. (2012). Effects of breast health education conducted by trained breast cancer survivors. Journal of Advanced Nursing, 68(5), 11001110. https://doi.org/10.1111/j.1365-2648.2011.05815.x 